Proc. Estonian Acad. Sci. Biol. Ecol., 2006, 55, 3, 228-242

\title{
Sedimentation dynamics in a small dimictic lake in northern Estonia
}

\author{
Jaanus Terasmaa* and Jaan-Mati Punning \\ Institute of Ecology at Tallinn University, Uus-Sadama 5, 10120 Tallinn, Estonia \\ Received 4 August 2005, in revised form 28 November 2005
}

\begin{abstract}
During a yearlong observation, settling fluxes of seston in the epilimnion and hypolimnion of Lake Viitna Linajärv varied from 230 to $1400 \mathrm{mg} \mathrm{m}^{-2} \mathrm{~d}^{-1}$. Most of the seston consisted of particulate organic matter (POM). The POM content in the dry matter of surface sediments sampled from the entire lake floor was on average over $50 \%$. Seasonal changes in the distribution of chlorophyll $a$ in the lake and the content of POM reveal the important role of fresh planktonic particles in the deposition. A strong correlation between POM and particulate inorganic matter in the settling matter during stratification indicates flocculent settling of the mineral particles. Resuspension from the littoral zone results in the focusing of sediment into the deep basin of the lake.
\end{abstract}

Key words: small lakes, seston fluxes, sedimentation velocity, sediment focusing, aggregate dynamics.

\section{INTRODUCTION}

The study of seston fluxes in lakes is important for understanding matter circulation within lakes and the state and development of lake ecosystems. Spatial and temporal patterns of the seston flux and interactions at the water-sediment interface are also crucial for palaeoecological interpretation of the information stored in sediments as well as for estimating internal pollution fluxes in water bodies (Meyers \& Ishiwatari, 1995; Meyers \& Teranes, 2001).

Because the spatio-temporal regularities of horizontal and vertical matter fluxes determine the sedimentation regime and redistribution of settling matter within lake basins, studies of this type are also applicable to palaeolimnological research (Bloesch, 1995). Davis \& Ford (1982) showed that sediment focusing can change

\footnotetext{
* Corresponding author, jaanus.terasmaa@tlu.ee
} 
over time, which could result in misinterpretation of palaeoecological records from individual sediment cores. Stability of sediment on inclines requires forces such as cohesion and friction within the sediment to be greater than gravitational forces (Dearing, 1997). Many recent studies have been concerned with these issues.

One of the most common methods to measure particle cycling is the application of vertical series of sediment traps complemented with analysis of surface sediments. Sediment trap data have been used to measure matter fluxes in the water column (Bloesch \& Uehlinger, 1986), the availability of matter to sediment surface (Weyhenmeyer et al., 1995; Heiskanen, 1998), and to analyse sediment resuspension in lakes of different morphometry (Shteinman \& Parparov, 1997; Mieszczankin \& Noryskiewicz, 2000). These studies show that resuspension in large lakes, where wind-induced water currents, wave action, and subsequent seiches play an important role, depends on morphological parameters (Håkanson \& Jansson, 1983; Rowan et al., 1992; Weyhenmeyer, 1996). In small lakes, where the impact of wind and wave activity is limited, resuspension is more dependent on the lake morphometry and thermal regime (Terasmaa, 2005). In this paper our approach is to apply different indicators to distinguish the spatio-temporal fluxes of particulate matter.

This research had the following main objectives: (1) to describe and quantify the seasonal dynamics of settled particulate matter; (2) to estimate the portion of newly formed particulate organic matter in the seston fluxes and aggregate dynamics; and (3) to study the mechanisms of sediment transport in a small dimictic lake.

\section{MATERIAL AND METHODS}

\section{Study site}

The study was carried out in Lake Viitna Linajärv (hereafter L. Linajärv) situated in Lahemaa National Park in northern Estonia $\left(59^{\circ} 27^{\prime} 06^{\prime \prime} \mathrm{N}, 26^{\circ} 00^{\prime} 52^{\prime \prime} \mathrm{E}\right)$ (Fig. 1). The surrounding territory features limno- and fluvioglacial sediments. Steep eskers flank the lake to the west and south. The catchment area, excluding the lake, is 38 ha. The lake has no outlet or inlet and the water level is controlled mainly by groundwater.

Lake Linajärv is a dimictic eutrophicated lake with an area of 3.8 ha (length $350 \mathrm{~m}$, maximum width $170 \mathrm{~m}$ ) and is elongated from north to south (Fig. 1b). The lake has an average depth of $1.8 \mathrm{~m}$ with a maximum depth of $5 \mathrm{~m}$ in the southern end. The mean depth of the northern part of the lake is 1-2 m. The dynamic ratio (see Håkanson \& Jansson, 1983) of the lake is 0.11 . Most of the lake basin area (about $66 \%$ ) features inclines $<5 \%$, whereas grades of $5-14 \%$ cover approximately $32 \%$. The area of sediment erosion and transport (calculated based on the model of Håkanson \& Jansson, 1983) currently comprises $22 \%$ of the lake bottom. 


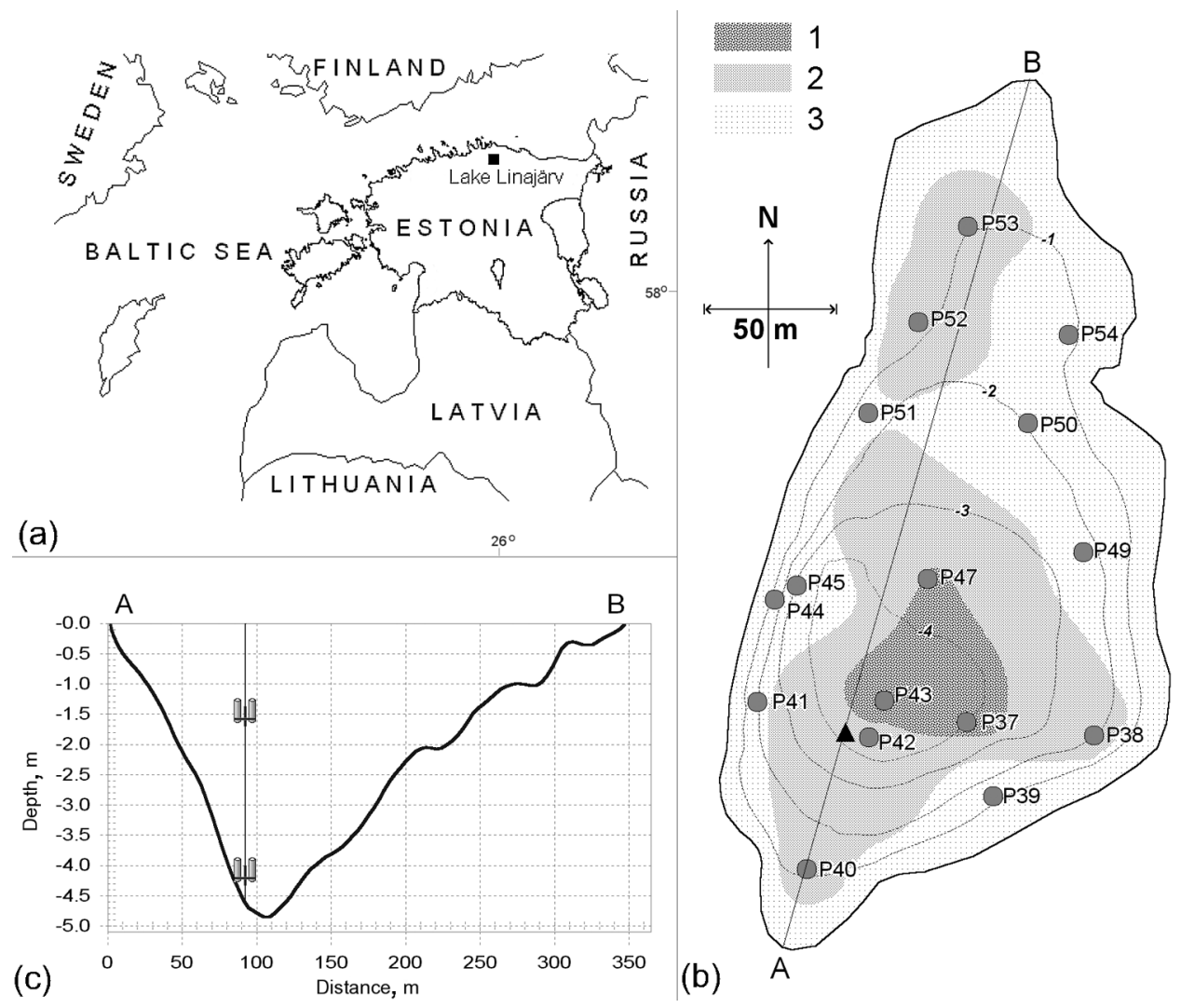

Fig. 1. The location of Lake Linajärv (a); bathymetry (m), silt and clay content (grain size $<0.63 \mu \mathrm{m}$ ) in mineral matter ( 1 - over $60 \%, 2-30-60 \%, 3$ - less than 30\%); coring sites (grey circles) and location of the sediment traps (black triangle) (b); and topography on the profile $\mathrm{AB}$ (see b) and location of sediment traps (c).

During the summer the thermocline descends from a depth of about $2.5 \mathrm{~m}$ in June to $3-3.5 \mathrm{~m}$ in July-August. Approximately $60 \%$ of the lake bottom is considered to be within the epilimnion during the stratification period. The oxygen concentration undergoes a distinct seasonal cycle. Its vertical gradient during the period of convective mixing is a consequence of higher consumption in the deeper layers compared to the supply by vertical transport. With the onset of stratification, organic matter rapidly depletes oxygen in the hypolimnion. The temperature decrease in September generates a gradual onset of autumnal circulation causing the water column to become unstratified by the end of October (Fig. 2).

The bottom sediments of L. Linajärv are up to $10 \mathrm{~m}$ thick in the deepest part of the basin. The upper $4 \mathrm{~m}$ of sediments consists of brownish gyttja with high water and organic matter contents. The average sediment accumulation rate of dry matter in the deepest area during the last 120 years is fairly even 


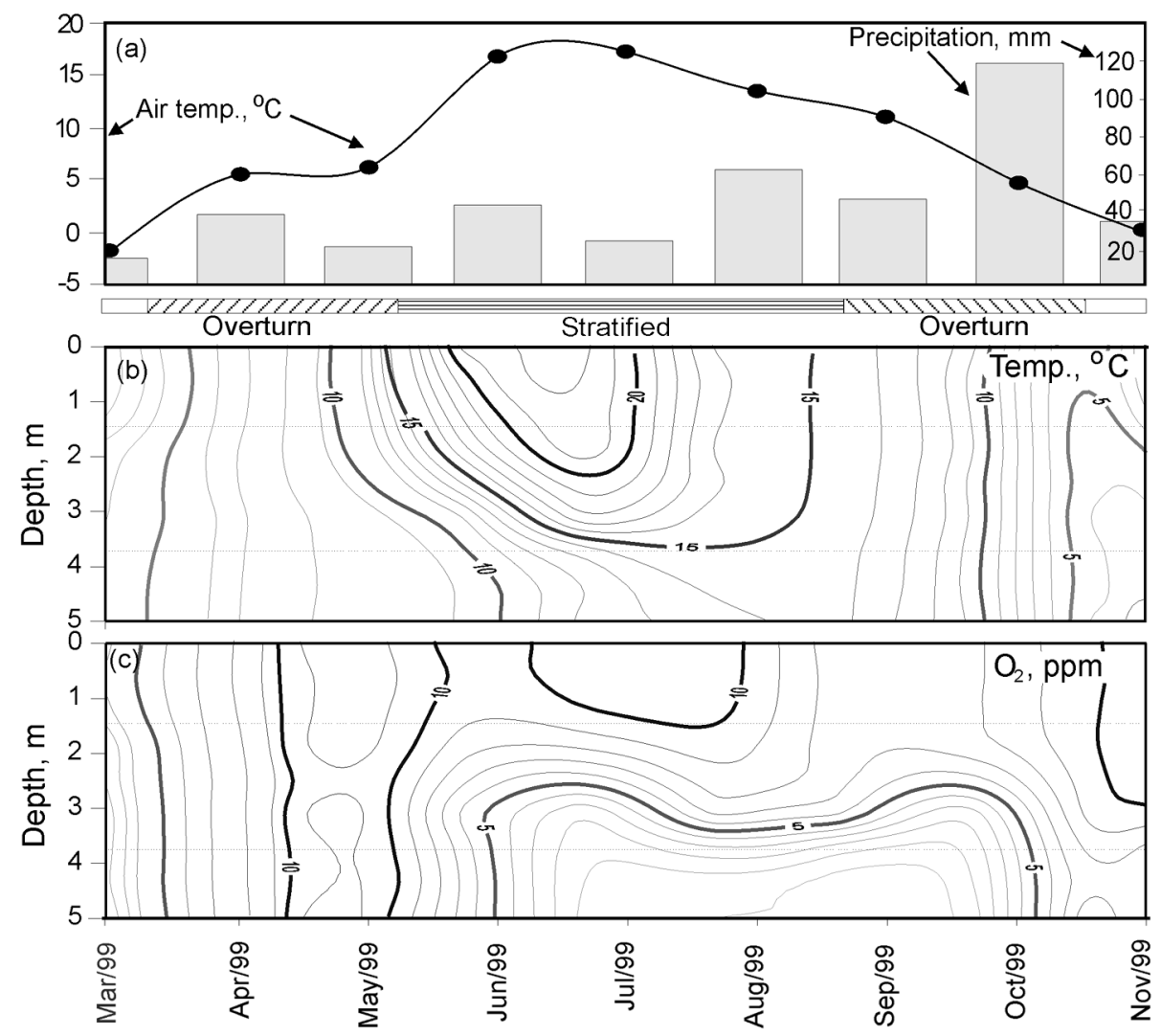

Fig. 2. Air temperature and precipitation (a), water temperature (b), and oxygen content (c) in L. Linajärv. Dotted lines denote the depth of the sediment traps.

$\left(0.021 \pm 0.01 \mathrm{~g} \mathrm{~cm}^{-2} \mathrm{yr}^{-1}\right)$ (Punning et al., 2004). Silt and clay particles $(\mathrm{d}<63 \mu \mathrm{m})$ comprise $20-30 \%$ of the bottom sediment in areas with water depth of 2-4 $\mathrm{m}$ and $50-60 \%$ in areas deeper than $4 \mathrm{~m}$ (Fig. 1).

Lake Linajärv was oligotrophic, but its previous intensive use for flax retting since the 18th century and the present use for swimming and recreation have led to eutrophication (concentration of chlorophyll $a\left(\mathrm{Chl} a\right.$ ) up to $605 \mu \mathrm{g} \mathrm{L}^{-1}$, primarily Gonyostomum semen (Ehr.) Dies., abundance of green algae, and changes in the size structure of the phytoplankton community; Punning \& Leeben, 2003).

\section{Sampling}

Two sediment traps were deployed in the deepest part of the lake $(5 \mathrm{~m})$ : one $1.0 \mathrm{~m}$ above the lake bottom and the other $1.3-1.5 \mathrm{~m}$ below the water surface (Fig. 1). The traps consisted of cylinders with a surface area of $43.54 \mathrm{~cm}^{2}$ and an 
aspect ratio of 5.6. As estimated in previous studies (Håkanson \& Jansson, 1983; Punning et al., 2002), this aspect ratio is required to prevent resuspension of the trapped material. The experiment ran for about one year, from 9 March 1999 until 25 April 2000, during which the traps were replaced six times. The trap exposure periods were chosen to reflect the seasonal development of the thermal regime, averaging one month during the stratification period and three to four months during the rest of the year (during the ice-free period). In order to avoid the complications in data analysis caused by unequal exposure periods, we calculated daily influx for each deployment period, which was then used to determine monthly rates (Fig. 3). Statistical analysis shows that such calculation does not compromise the data and relationships are revealed.

\begin{tabular}{|c|c|c|c|c|c|c|c|}
\hline $\begin{array}{c}\text { Trap exposure } \\
\text { period }\end{array}$ & $\begin{array}{l}\text { No. of } \\
\text { days }\end{array}$ & $\begin{array}{c}\text { Recalculated } \\
\text { intervals }\end{array}$ & $\begin{array}{l}\text { No. of } \\
\text { days }\end{array}$ & Month & $\begin{array}{l}\text { No. of } \\
\text { days }\end{array}$ & Season & $\begin{array}{c}\text { No. of } \\
\text { days }\end{array}$ \\
\hline $\begin{array}{l}\text { 09/Mar/1999- } \\
\text { 12/May/1999 }\end{array}$ & & $\begin{array}{l}\text { 01/Apr/1999-30/Apr/1999 } \\
\text { 01/May/1999-12/May/1999 }\end{array}$ & $\begin{array}{l}(30)- \\
(12) \\
(19)\end{array}$ & $\begin{array}{l}\text { Apr/99 } \\
\text { May/99 }\end{array}$ & $\begin{array}{l}(30) \\
(31)\end{array}$ & $\begin{array}{l}\text { Spring } \\
\text { (overturn) }\end{array}$ & (61) \\
\hline $\begin{array}{l}\text { 21/Jun/1999- } \\
\text { 24/Aug/1999 }\end{array}$ & (65) & $\begin{array}{l}\text { 01/Jun/1999-20/Jun/1999 } \\
\text { 21/Jun/1999-30/Jun/1999 } \\
\text { 01/Jul/1999-31/Jul/1999 } \\
\text { 01/Aug/1999-24/Aug/1999 } \\
\text { 25/Aug/1999-31/Aug/1999 }\end{array}$ & $\begin{array}{l}(20) \\
(10) \\
(31)- \\
(7)\end{array}$ & $\begin{array}{l}\text { Jun/99 } \\
\text { Jul/99 } \\
\text { Aug/99 }\end{array}$ & 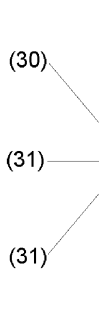 & $\begin{array}{l}\text { Summer } \\
\text { (stratified) }\end{array}$ & (92) \\
\hline 06/Oct/1999 & & $\begin{array}{l}\text { 01/Sep/1999-30/Sep/1999 } \\
\text { 01/Oct/1999-06/Oct/1999 }\end{array}$ & $\begin{array}{l}\text { (30) } \\
\text { (6) }\end{array}$ & Sep/99 & & & \\
\hline $\begin{array}{l}\text { 07/Oct/1999- } \\
\text { 10/Nov/1999 }\end{array}$ & . & $\begin{array}{l}\text { 07/Oct/1999-31/Oct/1999 } \\
\text { 01/Nov/1999-10/Nov/1999 } \\
\text { 11/Nov/1999-30/Nov/1999 }\end{array}$ & $\begin{array}{l}(25) \\
(10) \\
(20)\end{array}$ & $x^{2}$ & (30) & $\begin{array}{l}\text { Autumn } \\
\text { (overturn) }\end{array}$ & (91) \\
\hline 25/Apr/2000 & & $\begin{array}{l}\text { 01/Dec/1999-31/Dec/1999 } \\
\text { 01/Jan/2000-31/Jan/2000 } \\
\text { 01/Feb/2000-28/Feb/2000 } \\
\text { 01/Mar/2000-31/Mar/2000 }\end{array}$ & $\begin{array}{l}(31)- \\
(31)^{-} \\
(28)^{-} \\
(31)^{-}\end{array}$ & $\begin{array}{l}\text { Dec/99 } \\
\text { Jan/00 } \\
\text { Feb/00 } \\
\text { Mar/00 }\end{array}$ & $\begin{array}{l}(31) \\
(31) \\
(28) \\
(31)\end{array}$ & $\begin{array}{l}\text { Winter } \\
\text { (unstratified) }\end{array}$ & (122) \\
\hline
\end{tabular}

Fig. 3. Exposure periods of the traps and recalculated intervals. 
Upon removal of the traps and settling of the particles the water was decanted from the samples. The samples were dried at $105^{\circ} \mathrm{C}$ to a constant weight. The temperature and oxygen content in the water column were measured regularly at the study sites.

Sixteen short cores (up to $10 \mathrm{~cm}$ in length) from different parts of the basin (Fig. 1b) were taken using a modified Livingstone-Vallentyne sampler. Cores were packed in PVC boxes and refrigerated until analysis.

\section{Analytical procedures}

All sediment samples were analysed for water content and organic and mineral matter concentrations and trap samples for mineral and organic matter content. The concentration of dry matter in sediment was determined by drying the samples to a constant weight at $105^{\circ} \mathrm{C}$. Organic matter was estimated by loss-on-ignition (LOI) after heating at $550^{\circ} \mathrm{C}$ for $210 \mathrm{~min}$. Because of the small quantity of matter, the concentration of $\mathrm{C}$ and $\mathrm{N}$ was measured using a Fison Elemental Analyser EA II08 and calculated as percentage of dry mass at $105^{\circ} \mathrm{C}$. The $\mathrm{C} / \mathrm{N}$ ratio was calculated as mass ratio. Particulate organic matter (POM) in trap samples was calculated as twice the elemental $\mathrm{C}$ concentrations.

The granulometric composition of sediment samples was determined by wet sieving. Four metallic woven mesh sieves $(36,63,100$, and $315 \mu \mathrm{m})$ were stacked vertically and placed in a Vibratory Sieve Shaker "Analysette 3" PRO. A weighed subsample of sediment was placed into the upper sieve and after 15-20 min of shaking, the content of each sieve was weighed. Particle size partitioning was determined from the amount of sediment remaining in each specific sieve (Folk, 1980; Last, 2001). Grain size fractions were amalgamated into two groups: sand $(>63 \mu \mathrm{m})$ and silt and clay $(<63 \mu \mathrm{m})$. Cartographic analysis and visualization were made with computer programs MapInfo Professional 5.5 and VerticalMapper 2.5. Digital elevation models were interpolated and areas of specific sediment composition were determined from the sediment composition in different sampling points (shown in Fig. 1).

Chlorophyll $a$ in the water samples taken at depths 1, 2, and 3 m during MayOctober 1999 was determined spectrophotometrically with $90 \%$ acetone or ethanol as the extraction solvent. The concentration of Chl $a$ was calculated using the appropriate equations by Arvola (1981).

\section{RESULTS AND DISCUSSION}

\section{Seasonal fluxes of particulate matter in traps}

The influx of POM and particulate inorganic matter (PIM) into the upper (epilimnetic) and lower (hypolimnetic) traps displayed marked seasonal variation and a strong mutual relationship, especially during stratification (Fig. 4a,b). The 
influxes increased continuously from April until July and peaked during JulySeptember (lower trap) and July-August (upper trap). Subsequent sedimentation decreased rapidly to minimum values by winter (unstratified period). In addition, the influx into the lower traps exceeded that of the upper traps up to 2.7 times during the summer and 1.1-1.3 times at other times. Although this difference has been noted previously (see Bloesch, 1995), the difference in L. Linajärv is significantly lower than in larger lakes, where surface waves and internal seiches can cause greater resuspension and settling of particles in the hypolimnion. For example, during stratification in L. Erken (Sweden), the settled matter in hypolimnetic traps exceeded that in epilimnetic traps by a factor of up to 45 (Weyhenmeyer, 1996).

The increase in particulate influx in both the epilimnion and hypolimnion traps was concurrent with the onset of stratification, which began in mid-May. By the beginning of June stable stratification was established at a depth of $2.5-3.0 \mathrm{~m}$. From then until mid-September the upper trap occupied the epilimnion and the lower trap the hypolimnion (Figs 1 and 2). During the stratification period the air temperature was stable with relatively low precipitation and without any extremely strong winds.

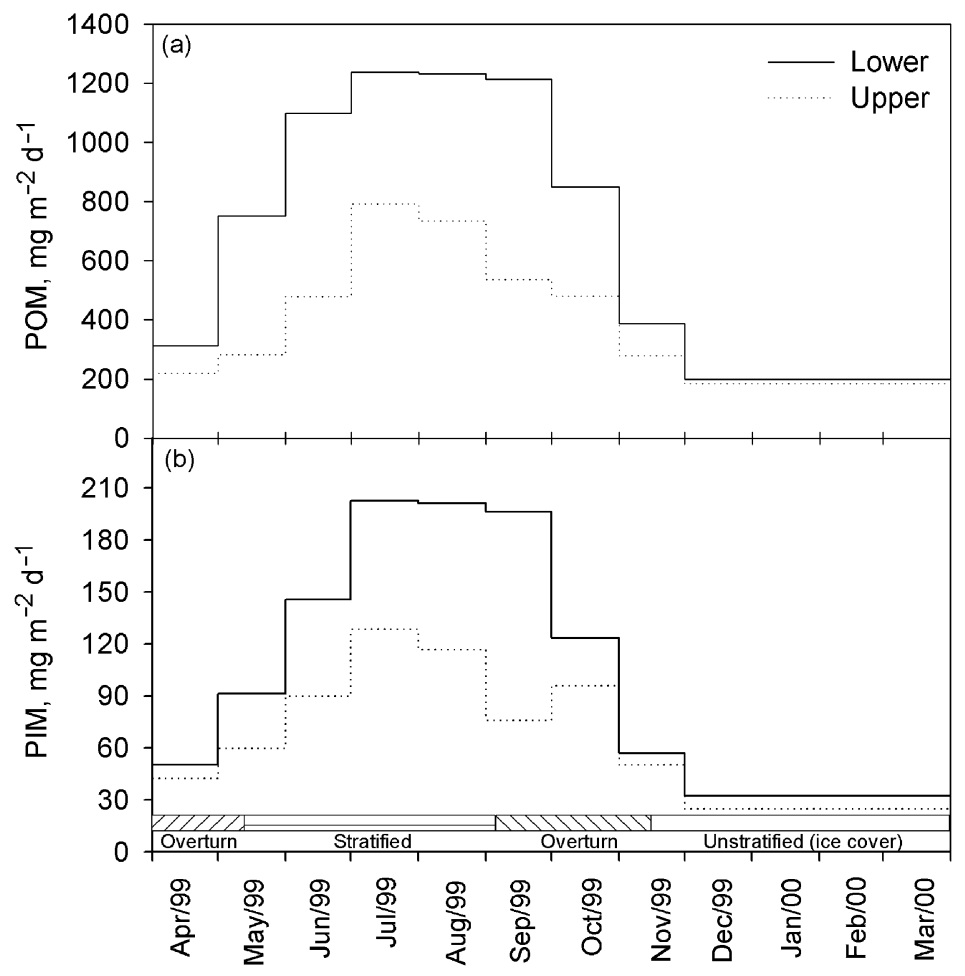

Fig. 4. Influx into lower and upper traps during recalculated intervals $\left(\mathrm{mg} \mathrm{m}^{-2} \mathrm{~d}^{-1}\right)$ : (a) particulate organic matter (POM) and (b) particulate inorganic matter (PIM). 


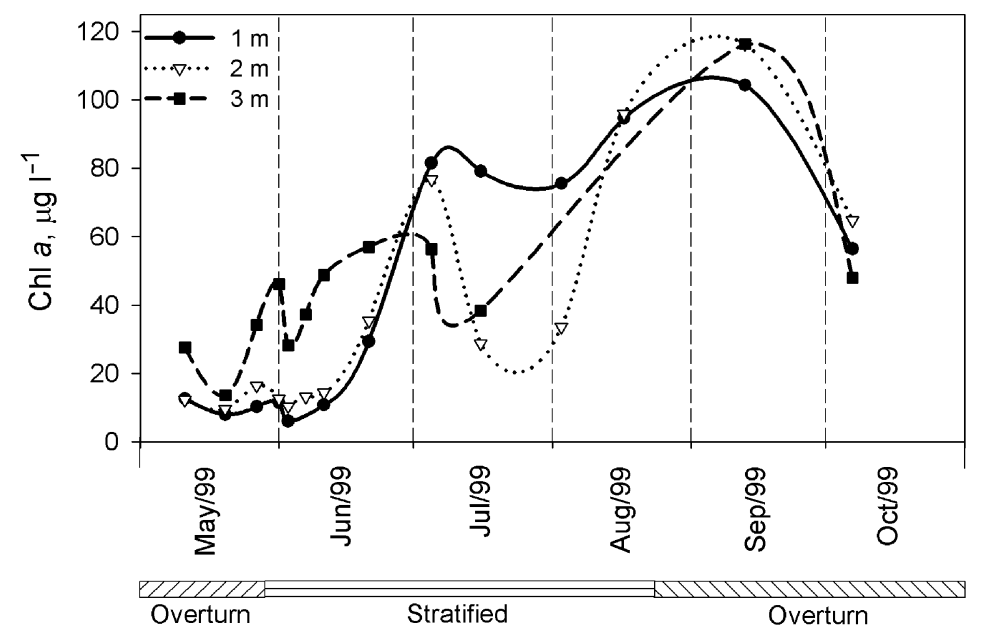

Fig. 5. Temporal changes in $\mathrm{Chl} a$ concentrations at depths of 1, 2, and $3 \mathrm{~m}$ (A. Leeben, unpublished data).

The trapped particulate matter consisted of newly produced planktonic matter, allochthonous PIM, and a secondary flux of previously settled matter (PIM and POM). The distribution of Chl $a$ provided an insight into the seasonal variation of the fresh autochthonous biomass in the settling matter. Figure 5 displays the temporal trend of Chl $a$ concentration at different depths. The Chl $a$ and oxygen content in the vertical water profile indicates that phytoplankton production began in April-May and was more intensive in the hypolimnion until the end of June. Because the highest concentrations of Chl $a$ tend to occur in the deeper layers (below the Secchi disc depth), the relationship between the water transparency and the pigment concentration is weak. The largest variation in Chl $a$ concentration with depth was in July-August when the intensity of bioproduction was greater in the surface (epilimnetic) layers. During August another algal bloom occurred, and until the end of September the Chl $a$ concentration in the upper $3 \mathrm{~m}$ was uniform and high. An analogous seasonal vertical distribution of Chl $a$ in L. Linajärv was noted in 1975 and 1976 by Milius \& Kõvask (1978), who detected a strong correlation between Chl $a$ and total bioproduction. Therefore we use here Chl $a$ concentration as an index of phytoplankton production.

\section{Sedimentation dynamics}

The settling rates of POM corresponded well with the seasonal variations of Chl $a$ concentrations in the vertical water column. The POM differential between the lower and upper traps peaked in May-June, when higher concentrations of $\mathrm{Chl} a$ were found at depths of 2-3 m. The high POM influx into the lower trap in September may have been due to deterioration in stratification, which impeded sinking. 
The dominance of fresh organic matter in the entrapped sediment is demonstrated by the variations in $\mathrm{C} / \mathrm{N}$ ratios (Fig. 6). Because of differences in the protein content, lower $\mathrm{C} / \mathrm{N}$ values indicate a larger planktonic component in the organic matter (if selective microbial destruction is insufficient) (Wetzel, 1983; Nakai, 1986; Hassan et al., 1997). The decreasing $\mathrm{C} / \mathrm{N}$ ratio in both traps from April to October suggests a steady increase in planktonic matter $(\mathrm{C} / \mathrm{N}$ average values in planktonic matter are about 6; Bowen, 1966). As there is no inlet to the lake, the remaining entrapped POM originated from macrophytes and resuspended sedimentary matter.

The average $\mathrm{C} / \mathrm{N}$ ratio of the six surface sediment samples $(0-10 \mathrm{~cm})$ was 10.4. During the year the $\mathrm{C} / \mathrm{N}$ ratio of organic matter in the traps varied from 9.6 in April to 6.8 in October. Assuming that the entrapped POM consists mainly of redeposited sediment surface matter and authocthonous planktonic matter $(\mathrm{C} / \mathrm{N}=6)$, the portion of redeposited organic matter is largest in spring, forming roughly $80 \%$ of the total (Punning \& Tõugu, 2000). As bioproduction in the lake increases, the proportion of fresh organic matter increases as well, decreasing the amount of redeposited POM to $15 \%$.

The temporal distribution of entrapped sediment in the epilimnion and hypolimnion clearly shows that most particulate matter settles during the summer stratification. During this period the covariance of settled POM and PIM is strong (consequently $R=0.9 ; p<0.01$ ). Therefore, both organic and inorganic components have followed similar pathways within the lake. As indicated, fresh planktonic matter dominates POM during the summer stratification. Therefore, it would not be logical to assume that the changes in the erosional influx of allochthonous mineral matter are as regular as inorganic matter; besides, the lake under study is small and is located in a glaciokarstic hollow with forested shores, which hinders nearshore erosion (Håkanson \& Jansson, 1983). Resuspension of bottom sediment

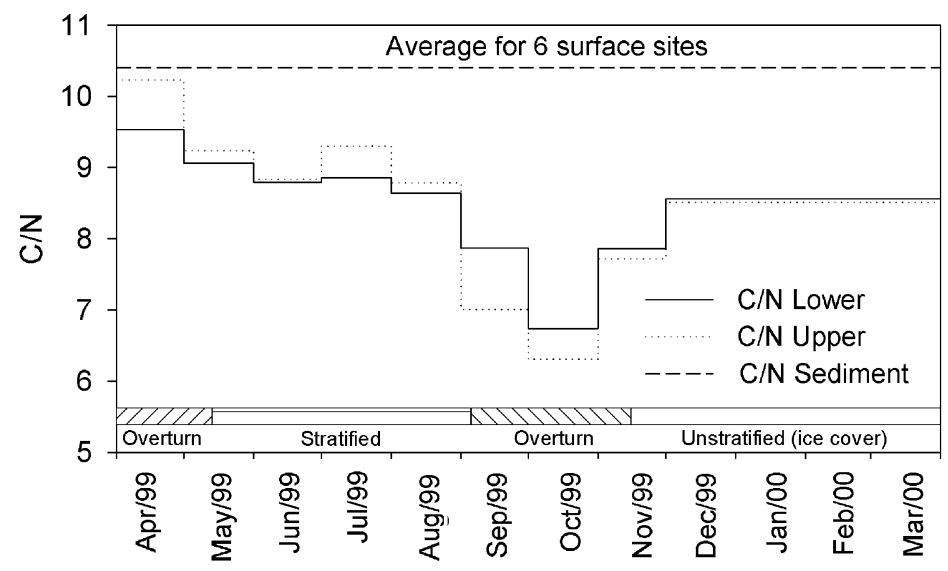

Fig. 6. $\mathrm{C} / \mathrm{N}$ ratio in organic matter in the traps and average value of 6 surface sites. Increase of $\mathrm{C} / \mathrm{N}$ values denotes an increase of the share of nonplanktonic organics in traps. 
(mostly silt and clay) from the deepest region of the lake (Fig. 1b) requires bottom current velocities $>7 \mathrm{~cm} \mathrm{~s}^{-1}$ (Bloesch, 1995). Currents of this magnitude are unlikely to occur, especially during stratification. Our previous study of L. Linajärv revealed an as high as $0.99(p<0.01)$ correlation between mineral and organic matter in the surface sediment in the deeper areas, which decreased to 0.5 $(p<0.01)$ near the upper limit of the accumulation zone (Punning et al., 2004).

Many studies have shown that the qualitative composition and character of seston - its capacity to dissolve, precipitate, and coagulate - dictate the kinetics of particle accumulation, i.e., that gravitational settling is complicated when particle aggregation takes place. Studies of L. Maggiore (Italy) indicate sinking velocities of $\sim 0.5 \mathrm{~m} \mathrm{day}^{-1}$ for particles $<10 \mu \mathrm{m}$ in diameter and $0.8 \mathrm{~m}^{-1 a y}{ }^{-1}$ for particles of $10-50 \mu \mathrm{m}$ (Callieri, 1997). Seston sinking rates of phytoplankton assemblages in L. Erken were established to be $2-4 \mathrm{~cm} \mathrm{day}^{-1}$ (Rodrigo et al., 1998). As the transport of fine-grained particles (especially those $<50 \mu \mathrm{m}$ in diameter; Georgian et al., 2003) is affected greatly by capture by larger particles or aggregation; their deposition rate and thus the mechanisms of their accumulation might also vary.

Our results explain those mechanisms: fresh planktonic matter, which incorporates fine-grained particles from the nearshore area, chiefly controls the influx of PIM. Thus, the deposition of mineral matter sedimented is associated with flocculation of sinking organic, mainly phytoplankton, particles.

\section{Lateral redistribution of settled matter}

The dominating role of fresh planktonic matter in the seston fluxes, the shape and size of the lake basin (see Fig. 1; Punning et al., 2003), small fluxes into traps during turnover, and the granulometric characteristics of sedimented particles suggest that the resuspension of settled matter from the hypolimnetic (deeper) areas in L. Linajärv is hindered.

Granulometric analysis of surface sediment samples showed that fine-grained fractions $(<63 \mu \mathrm{m})$ dominate in deeper areas with a smoother relief (Table 1), whereas areas of steeper inclines feature coarser fractions. The silt and clay fraction of mineral matter varies from $1 \%$ in the samples taken in the littoral area to $70 \%$ in the samples from the deeper, central area. Statistical analysis shows that the lithological composition and distribution of the silt and clay fraction in sediments are closely associated with the lake bottom topography (Table 2). The strongest correlation was established between the silt and clay content and the distance of coring sites to the shore $(R=-0.73, p>0.01)$. Grain size also correlates significantly with water depth and slope inclinations. These relationships are indicative of the resuspension of fine-grain particles and their transport to deeper areas. That is, suspended mineral matter in the water likely originates from the nearshore area and the principal mechanism in the lateral transportation of sediments in the lake is focusing, as described by Ohle (1962) and other authors (Lehman, 1975; Davis et al., 1985). 
Table 1. The lithological composition and share of the silt and clay fraction in the surface sediment samples in L. Linajärv and characteristics of the study sites. Min - minimum value, Q1 - first quartile, Q3 - third quartile, Max - maximum value

\begin{tabular}{l|c|c|c|c|c|c}
\hline $\begin{array}{c}\text { Core (see } \\
\text { Fig. 1b) }\end{array}$ & $\begin{array}{c}\text { Water } \\
\text { content, } \\
\%\end{array}$ & $\begin{array}{c}\text { LOI, } \\
\%\end{array}$ & $\begin{array}{c}\text { Silt and clay } \\
(<63 \mu \mathrm{m}), \\
\%\end{array}$ & $\begin{array}{c}\text { Water depth, } \\
\mathrm{m}\end{array}$ & $\begin{array}{c}\text { Underwater } \\
\text { incline, } \\
\%\end{array}$ & $\begin{array}{c}\text { Distance } \\
\text { to the shore, } \\
\mathrm{m}\end{array}$ \\
\hline P-37 & 98.4 & 80.3 & 67.1 & 4.1 & 5.7 & 48.0 \\
P-38 & 96.6 & 63.2 & 32.7 & 2.3 & 7.2 & 19.0 \\
P-39 & 39.0 & 1.8 & 0.3 & 1.6 & 7.8 & 18.0 \\
P-40 & 94.1 & 61.8 & 39.1 & 1.1 & 4.0 & 17.0 \\
P-41 & 93.9 & 47.3 & 28.8 & 2.1 & 10.5 & 11.0 \\
P-42 & 98.3 & 79.8 & 54.7 & 4.9 & 5.1 & 54.0 \\
P-43 & 98.4 & 81.2 & 69.2 & 4.4 & 0.4 & 59.0 \\
P-44 & 55.4 & 4.4 & 0.4 & 1.8 & 22.3 & 8.0 \\
P-45 & 93.8 & 39.8 & 5.7 & 2.4 & 18.8 & 15.0 \\
P-47 & 98.2 & 80.1 & 60.5 & 3.9 & 1.5 & 61.0 \\
P-49 & 95.1 & 51.9 & 23.5 & 2.2 & 4.3 & 31.0 \\
P-50 & 86.9 & 23.2 & 8.0 & 1.9 & 3.1 & 31.0 \\
P-51 & 96.1 & 63.8 & 28.7 & 1.8 & 6.3 & 15.0 \\
P-52 & 97.0 & 75.3 & 55.8 & 1.3 & 5.2 & 19.0 \\
P-53 & 97.6 & 75.0 & 38.2 & 0.9 & 1.8 & 36.0 \\
P-54 & 94.4 & 42.1 & 9.1 & 1.4 & 2.0 & 20.0 \\
Min & 39.0 & 1.8 & 0.3 & 0.9 & 0.4 & 8.0 \\
Q1 & 93.9 & 41.5 & 69.2 & 1.6 & 2.8 & 16.5 \\
Median & 95.6 & 62.5 & 32.6 & 2.0 & 5.2 & 19.5 \\
Q3 & 97.8 & 76.4 & 30.7 & 2.8 & 7.4 & 39.0 \\
Max & 98.4 & 81.2 & 0.3 & 4.9 & 22.3 & 61.0 \\
& & & & & & \\
\end{tabular}

Table 2. Correlation coefficients (Pearson correlation) between the LOI, content of water and the silt and clay fraction in surface sediments and water depth, slope inclination, and distance to the shore in L. Linajärv. Bold values denote significant correlation $(p<0.01)$, underlined coefficients denote moderately strong relationships $(p<0.05)$, and coefficients in regular font denote weak relationships $(p=\mathrm{NS})$

\begin{tabular}{l|c|c|c|c|c}
\hline & $\begin{array}{c}\text { LOI, } \\
\%\end{array}$ & $\begin{array}{c}\text { Silt \& clay } \\
(<63 \mu \mathrm{m}), \\
\%\end{array}$ & $\begin{array}{c}\text { Water } \\
\text { depth, } \\
\mathrm{m}\end{array}$ & $\begin{array}{c}\text { Underwater } \\
\text { inclination, } \\
\%\end{array}$ & $\begin{array}{c}\text { Distance } \\
\text { to shore, } \\
\mathrm{m}\end{array}$ \\
\hline Water content, \% & $\mathbf{0 . 8 4}$ & $\underline{-0.62}$ & 0.29 & -0.47 & 0.40 \\
LOI, \% & & $-\mathbf{0 . 9 1}$ & 0.47 & $\underline{-0.58}$ & $\underline{\underline{0.63}}$ \\
Silt \& clay $(<63 \mu \mathrm{m}), \%$ & & $\underline{-0.62}$ & $\underline{\underline{0.55}}$ & $\mathbf{- 0 . 7 3}$ \\
Water depth, m & & & -0.16 & $\mathbf{0 . 8 0}$ \\
Underwater inclination, \% & & & & $\underline{0.59}$
\end{tabular}


As a result of multiple deposition and resuspension, PIM can frequently establish a uniform redistribution (Evans, 1994). Similarly, Veronesi et al. (2002) estimated that lateral transport and focusing prevail over pelagic resuspension. This type of focusing in Mirror Lake (USA) is described in detail by Davis et al. (1985). The dynamics of fine-grained matter within the lake is greatly determined by the spatio-temporal distribution of fresh organic matter and the dynamics of aggregation. Also the thermal regime and stratification affect the sinking velocity. In Blue Chalk Lake (Canada), which has similar size and morphology with L. Linajärv, the portion of resuspended matter in the epilimnion trap is lowest during stratification (Evans, 1994). As our previous studies in similar Lake Jussi in northern Estonia showed (Punning et al., 2003), a thermocline can hinder the particle deposition from the epilimnion. Only 1-2 months after the period of an intensive pollination of pine the amount of pine pollen in the upper trap exceeded that in the trap exposed at a depth of ca $3 \mathrm{~m}$. The calculated average sinking velocity of pine pollen during the stratification period is as low as $6-8 \mathrm{~cm} \mathrm{day}^{-1}$.

As the $\mathrm{C} / \mathrm{N}$ variation indicates, the greater abundance of particulate matter in the lower trap results from the vertical distribution of suspended matter in the lake rather than from the resuspension of matter from the lake floor. This was also observed by many other researchers (Ohle, 1962; Stocker \& Imberger, 2003). At the onset of stratification the $\mathrm{C} / \mathrm{N}$ values in the upper trap are slightly higher than in the lower trap, a result of secondary plankton-deficient seston from nearshore areas during the spring overturn. As bioproduction in the lake increases and the amount of resuspended organic matter in the water column decreases, seston in the epilimnion becomes richer in planktonic matter and $\mathrm{C} / \mathrm{N}$ decreases (Fig. 6). The autumn overturn in October-November had no essential impact on the redeposition (Figs 2 and 4).

\section{CONCLUSIONS}

This study of seston flux and surface sediment in Lake Linajärv clearly shows the significance of fresh plankton in the settled matter. The results indicate that particulate matter deposition is governed by particle aggregation, principally by sinking planktonic matter with high sorption capacity. Therefore, the most intensive sedimentation occurs during spring-summer.

Nearshore erosion and lateral transport of resuspended particulate matter seem to be responsible for redeposition in L. Linajärv. Statistical analysis suggests that the distribution of granulometric fractions in the surface samples is related to bottom topography. For example, differences in particle size and physicalchemical properties determine the deposition velocity and thus the distance between the primary settling point on the lake bottom surface and the secondary particle accumulation area. This might create significant heterogeneity in the composition 
of synchronous sedimentary layers. Moreover, sediment composition correlates with water depth, slope inclination, and distance from the shore. Therefore, the focusing depends on the lake bottom topography, which can change with time.

\section{ACKNOWLEDGEMENTS}

This study was supported by the Estonian Ministry of Education (targetfinanced project 0282120s02) and the Estonian Science Foundation (grant No. 5584). We thank T. Koff, M. Kangur, and A. Leeben for support in the field and laboratory work. We cordially thank Professor Margaret B. Davis for her helpful comments and suggestions.

\section{REFERENCES}

Arvola, L. 1981. Spectrophotometric determination of chlorophyll $a$ and phaeopigments in ethanol extractions. Ann. Bot. Fenn., 18, 221-227.

Bloesch, J. 1995. Mechanisms, measurement and importance of sediment resuspension in lakes. Mar. Freshwater Res., 46, 295-304.

Bloesch, J. \& Uehlinger, U. 1986. Horizontal sedimentation differences in a eutrophic Swiss lake. Limnol. Oceanogr., 31, 1049-1109.

Bowen, H. J. M. 1966. Trace Elements in Biochemistry. Academic Press, London.

Callieri, C. 1997. Sedimentation and aggregate dynamics in Lake Maggiore, a large, deep lake in Northern Italy. Mem. Ist. Ital. Idrobiol., 56, 37-50.

Davis, M. B. \& Ford, M. S. 1982. Sediment focusing in Mirror Lake, New Hampshire. Limnol. Oceanogr., 27, 137-150.

Davis, M. B., Ford, M. S. \& Moeller, R. E. 1985. Paleolimnology. In An Ecosystem Approach to Aquatic Ecology: Mirror Lake and Its Environment (Likens, G. E., ed.), pp. 345-366. Springer-Verlag, New-York.

Dearing, J. A. 1997. Sedimentary indicators of lake-level changes in the humid temperate zone: a critical review. J. Paleolimnol., 18, 1-14.

Evans, R. D. 1994. Empirical evidence of the importance of sediment resuspension in lakes. Hydrobiologia, 284(1), 5-12.

Folk, R. L. 1980. Petrology of Sedimentary Rocks. Hemphill Publishing Company, Austin.

Georgian, G., Newbold, J. D., Thomas, S. A., Monaghan, M. T., Minshall, G. W. \& Cushing, C. E. 2003. Comparison of corn pollen and natural fine particulate matter transport in streams: can pollen be used as a seston surrogate? J. North Am. Benthol. Soc., 22(1), 2-16.

Håkanson, L. \& Jansson, M. 1983. Principles of Lake Sedimentology. Springer-Verlag, Berlin.

Hassan, K. M., Swinehart, J. B. \& Spalding, R. F. 1997. Evidence for Holocene environmental change from $\mathrm{C} / \mathrm{N}$ ratio, and $\delta^{13} \mathrm{C}$ and $\delta^{15} \mathrm{~N}$ values in Swan Lake sediments, western Sand Hills, Nebraska. J. Paleolimnol., 18, 121-130.

Heiskanen, A.-L. 1998. Factors Governing Sedimentation and Pelagic Nutrient Cycles in the Northern Baltic Sea. Monographs of the Boreal Environment Research 8. Finnish Environment Institute, Helsinki.

Last, W. M. 2001. Textural analysis of lake sediments. In Tracking Environment Change Using Lake Sediments, Vol. 2. Physical and Geochemical Methods (Last, W. M., ed.), pp. 41-81. Kluwer Academic Publisher, London. 
Lehman, J. T. 1975. Reconstructing the rate of accumulation of lake sediment: the effect of sediment focusing. Quat. Res., 5, 541-550.

Meyers, P. A. \& Ishiwatari, R. 1995. Organic matter accumulation records in lake sediments. In Physics and Chemistry of Lakes (Lerman, A., Imboden, D. M. \& Gat, J. R., eds), pp. 279328. Springer-Verlag, Berlin.

Meyers, P. A. \& Teranes, J. L. 2001. Sediment organic matter. In Tracking Environmental Change Using Lake Sediments, Vol. 2. Physical and Geochemical Methods (Last, W. M., ed.), pp. 239-269. Kluwer Academic Publishers, London.

Mieszczankin, T. \& Noryskiewicz, B. 2000. Processes that can disturb the chronostratigraphy of laminated sediments and pollen deposition. J. Paleolimnol., 23, 129-140.

Milius, A. \& Kõvask, V. 1978. Seasonal variation of phytoplankton biomass, chlorophyll $a$ content and phosphate activity in lake Viitna Linajärv. Proc. Acad. Sci. Estonian SSR, Biol., 27, 306-313 (in Russian).

Nakai, N. 1986. Paleoenvironmental features of Lake Biwa deduced from carbon isotope compositions and organic $\mathrm{C} / \mathrm{N}$ ratios of the upper $800 \mathrm{~m}$ samples of $1400 \mathrm{~m}$ cored column. Proc. Jpn. Acad., 62, 279-282.

Ohle, W. 1962. Der Stoffhaushalt der Seen als Grundlage einer allgemeinen Stoffwechseldynamik der Gewässer. Kiel. Meeresforsch., 18, 107-120.

Punning, J.-M. \& Leeben, A. 2003. A comparison of sediment and monitoring data: implications for paleomonitoring a small lake. Environ. Monit. Assess., 89, 1-15.

Punning, J.-M. \& Tõugu, K. 2000. C/N ratio and fossil pigments in sediments of some Estonian lakes: an evidence of human impact and Holocene environmental change. Environ. Monit. Assess., 64, 549-567.

Punning, J.-M., Koff, T., Alliksaar, T. \& Terasmaa, J. 2002. Tracing the pathways of particles settling into a small lake. Proc. Estonian Acad. Sci. Biol. Ecol., 51, 227-241.

Punning, J.-M., Terasmaa, J., Koff, T. \& Alliksaar, T. 2003. Seasonal fluxes of particulate matter in a small closed lake in northern Estonia. Water Air Soil Pollut., 149(1), 77-92.

Punning, J.-M., Alliksaar, T., Terasmaa, J. \& Jevrejeva, S. 2004. Recent patterns of sediment accumulation in a small closed eutrophic lake revealed by the sediment records. Hydrobiologia, 529(1), 71-81.

Rodrigo, M. A., Pierson, D. C., Petterson, K., Kaup, E. \& Padisák, J. 1998. Sinking and floating rates of natural phytoplankton assemblages in Lake Erken. Arch. Hydrobiol. Special issues: Advances Limnol., 51, 143-156.

Rowan, D. J., Kalff, J. \& Rasmussen, J. B. 1992. Estimating the mud deposition boundary depth in lakes from wave theory. Can. J. Fish. Aquat. Sci., 49, 2490-2497.

Shteinman, B. S. \& Parparov, A. S. 1997. An approach to particulate matter transfer studies in littoral zones of lakes with changing morphometry. Water Sci. Technol., 36(4), 199-205.

Stocker, R. \& Imberger, J. 2003. Horizontal transport and dispersion in the surface layer of a medium-sized lake. Limnol. Oceanogr., 48(3), 971-982.

Terasmaa, J. 2005. Bottom topography and sediment lithology in two small lakes in Estonia. Proc. Estonian Acad. Sci. Biol. Ecol., 54, 171-189.

Veronesi, M. L., Barbieri, A. \& Hanselman, K. W. 2002. Phosphorus, carbon and nitrogen enrichment during sedimentation in a seasonally anoxic lake (Lake Lugano, Switzerland). J. Limnol., 61(2), 215-223.

Wetzel, R. G. 1983. Limnology. Saunders College Publishing, Fort Worth, Philadelphia.

Weyhenmeyer, G. A., Meili, M. \& Pierson, D. C. 1995. A simple method to quantify sources of settling particles in lakes: resuspension versus new sedimentation of material from planktonic production. Mar. Freshwater Res., 46, 223-231.

Weyhenmeyer, G. A. 1996. The influence of stratification on the amount and distribution of different settling particles in Lake Erken. Can. J. Fish. Aquat. Sci., 53, 1254-1262. 


\title{
Sestonivood ja settimisdünaamika Põhja-Eesti dimiktilises väikejärves
}

\author{
Jaanus Terasmaa ja Jaan-Mati Punning
}

Viitna Linajärvel läbi viidud pikaajaliste uuringute eesmärgiks oli kirjeldada sestonivoogude sesoonset dünaamikat ja setete moodustumise mehhanisme dimiktilistes väikejärvedes. Uuringud näitasid, et järve epi- ja hüpolimnionis varieeruvad põhiliselt partikulaarsest orgaanilisest ainest koosnevad sestonivood piirides 230 kuni $1400 \mathrm{mg} \mathrm{m}^{-2} \mathrm{~d}^{-1}$. Orgaaniline aine domineerib (sisaldus 54-83\%) ka kogu järve ulatuses kogutud pindmistes setetes. Klorofülli $a$ jagunemine järves ja orgaanilise aine kontsentratsiooni seos sestonis osutab planktilise materjali suurele osakaalule settivas aines. Orgaanilise ja mineraalse aine sisalduse omavaheline kõrge korrelatsioon järve stratifikatsiooniperioodil settivas aines viitab nende sarnasele liikumisteele järves. Arvestades erinevaid sissekandemehhanisme, viitab selline korrelatsioon peenterise materjali agregeerumisele sadeneva planktoniga ja kaassadenemise suurele osatähtsusele peenterise materjali väljakandumisel järvest. Seega toimub ka põhiline materjali settimine kevadsuvisel perioodil. 